\title{
Restoration-Focused Germination and Development of Five Central Mexican Oak Species
}

\author{
Alfonso-Corrado Cecilia1, Campos Jorge Eduardo², Mendoza Ana ${ }^{3}$, Aguirre-Hidalgo Victor', \\ Valencia-Davalos Susana4, González-Adame Gabriel1, Wooden Garvey Fanny ${ }^{5}$, \\ Clark-Tapia Ricardo ${ }^{1^{*}}$ \\ ${ }^{1}$ Instituto de Estudios Ambientales, Universidad de la Sierra Juárez, Oaxaca, México \\ ${ }^{2}$ Laboratorio de Bioquímica Molecular-Unidad de Biotecnología y Prototipos (UBIPRO), Fes-IZTACALA, \\ Tlalnepantla, México \\ ${ }^{3}$ Instituto de Ecología, UNAM, Ciudad Universitaria, México, D.F., México \\ ${ }^{4}$ Herbario de la Facultad de Ciencias (FCME), Departamento de Biología Comparada, UNAM, Ciudad \\ Universitaria, México, D.F., México \\ ${ }^{5}$ Nova Universitas, Carretera a Puerto Ángel Km. 34.5, Ocotlán de Morelos, México \\ Email: rclark@juppa.unsij.edu.mx
}

Received 24 December 2013; revised 27 January 2014; accepted 12 February 2014

Copyright (C) 2014 by authors and Scientific Research Publishing Inc.

This work is licensed under the Creative Commons Attribution International License (CC BY).

http://creativecommons.org/licenses/by/4.0/

(c) (i) Open Access

\section{Abstract}

In the genus Quercus, regeneration by seed is reduced or absent in many species. The naturally protected area of the Sierra Fria, in Aguascalientes, Mexico contains forests that are fragmented and have been degraded due to human activities. The oak populations in this region demonstrate a very restricted sexual regeneration, with five of the most abundant species of this genus: Quercuseduardii, Q. grisea, Q. potosina, Q. resinosa and $Q$. sideroxyla presenting low seedling recruitment. In this study we evaluated seed viability and the effect of seed size on the germination, growth and survival of the trees, with the aim of recommending restoration and conservation program management actions for these oak species. In 2005 and 2006, 5000 acorns of each species were collected and viability, germination and growth experiments were performed in the laboratory and greenhouse. We found high seed viability and significant size effect $(P<0.05)$ on levels of germination, growth and survival of these five species of oaks. Our results suggest that environmental and ecological factors have implications for the quality of the seeds produced. This work provides a basis for low cost seed and appropriate management strategies for restoration programs.

*Corresponding author. 
Keywords

Acorns, Oak, Regeneration, Seed Size, Seed Viability

\section{Introduction}

In Mexico, oaks (Quercus spp.) are widely distributed in temperate forests, forming pure stands or associations with conifers or other species (Challenger, 1998; Valencia-Avalos, 2004). Oak forests occupy $9 \times 106$ ha of Mexican land and are located mainly in the mountainous regions of the country (Challenger, 1998). Between 127,000 and 167,000 ha of temperate forests are lost every year (Masera et al., 1999), affecting many areas of forests occupied by these species (Alfonso-Corrado et al., 2007). Deforestation of large areas of land has profound ecological and environmental effects (Greipsson, 2011) and entails the reduction or loss of biodiversity and ecosystem function and services (Brown \& Lugo, 1994; Esquivel et al., 2008; Chazdon et al., 2009).

Natural land recovery might occur eventually if secondary succession is allowed to prosper without any other disturbance (Lamb \& Gilmour, 2003; Greipsson, 2011). However, this process is slow, often obstructed, and its outcomes are uncertain (Brown \& Lugo, 1994; del Moral et al., 2007). When forest recovery is not possible by natural processes, human intervention is necessary, either to initiate or accelerate secondary succession. Doing this restores both ecosystem services and biodiversity (Chazdon, 2008; Greipsson, 2011). Several actions have been suggested to restore biodiversity in damaged ecosystems (Lamb \& Gilmour, 2003; Shono et al., 2007; Greipsson, 2011). Among these, planting tree species of ecological and economic importance seem to adequately reduce soil erosion, increase biological diversity and accelerate the natural recovery process (Lamb \& Gilmour, 2003; Lamb et al., 2005; Vieira \& Scariot, 2006). This action is particularly useful under certain conditions, including scenarios where the degraded land is distant from the remnant forest (which acts as a resource for plants and animals), or when seeds are poorly dispersed (Lamb \& Gilmour, 2003).

Some authors have suggested the use of native species in restoration programs considering that they are well adapted to the environment and therefore, are more likely to become established (Vázquez-Yañes \& Batiz, 1999; Lamb \& Gilmour, 2003). In Mexico, reforestation policies have been focused on nonnative species, resulting in failure in the restoration programs (Segura-Burciaga, 2005; Cervantes et al., 2008). Recently, these environmental policies have changed, to promote reforestation using native species (Vázquez-Yañes et al., 1999; Cervantes et al., 2008). Nonetheless, the processes of seed germination and seedling establishment of many oak native species that are useful for restoration of Mexican forests are far from being understood.

Despite the fact that several species of the genus Quercus produce viable acorns with high germination rates, their natural regeneration rate remains low (Zavala-Chávez \& García-Moya, 1997). Factors such as desiccation (Zavala-Chávez, 2004), fruit predation and parasitism (Kajimura \& Fukomoto, 2005), or irregular acorn production (Kelly \& Sork, 2002; Alfonso-Corrado et al., 2007) have been identified as causes of unsuccessful seedling establishment. Acorns are considered as recalcitrant because desiccation occurs in a short period of time after seed maturation (Zavala-Chávez, 2004).

After dispersal, recalcitrant seeds quickly lose their germination capacity due to exposure to low humidity levels (Kermode \& Finch-Savage, 2002; Zavala-Chávez, 2004). Daws et al. (2005) have suggested that a relatively large fruit increases germination rate and growth efficiency in recalcitrant species, thus reducing exposure time to predators, or investment of resources for defense. It has been reported that large acorns increase germination, seedling growth and survival rates (Navarro, 2006; Quero et al., 2007; Yi \& Yang, 2010).

In this study, observations of populations of five oak species (Quercus eduardii Trel., Q. grisea Liebm., Q. potosina Trel., Q. resinosa Liemb. and Q. syderoxyla Trel.), in the naturally protected area of Sierra Fria, Aguascalientes suggest that natural regeneration by acorns is infrequent. The Sierra Fría forest has been recognised as a priority area for conservation and identified at the regional level as a biodiversity hotspot in central Mexico (SEDESO, 1993). However, from 1930 to 1950, this forest was subject to intense degradation activities including timber extraction and the introduction of agriculture and grazing. This anthropogenic perturbation was responsible for damaging the oak population and also for the severe erosion of the forest's soils (Chapa- 
Bezanilla et al., 2008; Minnich et al., 1994).

Consequently, this study evaluates factors that affect germination of these species and also investigates those implications, in order to recommend low cost seed management actions for restoration purposes. The aims of this study were: 1) to estimate acorn viability; and 2) to evaluate the effect of acorn size on germination, seedling growth and survival rates of these species.

\section{Methods}

\subsection{Study Area}

The study was carried out in the protected natural area of Sierra Fria, Aguascalientes, Mexico (Figure 1), which is part of the floristic province of Sierra Madre Occidental that comprises an area of 112,090 ha. The area has a temperate, semi-dry climate; the rainy seasons is in summer, with a mean annual temperature of $14.5^{\circ} \mathrm{C}$, and a mean annual precipitation of $664 \mathrm{~mm}$. Vegetation is dominated by oak forests, or oak-pine forests at altitudes between 1900 and 3050 masl (SEDESO, 1993).

\subsection{Study Species}

For this study we select the five most abundant oaks species of Sierra Fria: 1) Quercuseduardii Trel. red oak (Lobatae), (trunk height, varying between 5 - 20 m), 2) Q. grisea, Liebm. White oak (Quercus), (trunk height, between 4 - $10 \mathrm{~m}$ ), 3) Q. potosina Trel. white oak (Quercus), (trunk height, varying between 3 - $15 \mathrm{~m}$ ), 4 ) Q. resinosaTrel. white oak (Quercus), (trunk height, varying between 6 - $10 \mathrm{~m}$ ), and 5) Q. sideroxyla Trel. red oak (Lobatae), (trunk heights varying between 5 and $30 \mathrm{~m}$ ) (Table 1).

\subsection{Data Collection}

During fruit production (August-November 2005), thirty-five individuals of each species were selected and approximately 100 to 200 acorns were collected directly from each individual, thus reducing seed damage from insects or other factors (Zavala-Chávez, 2004). A total number of 25,000 acorns (5000 of each species) were placed in plastic bags and taken to the laboratory for further analyses.

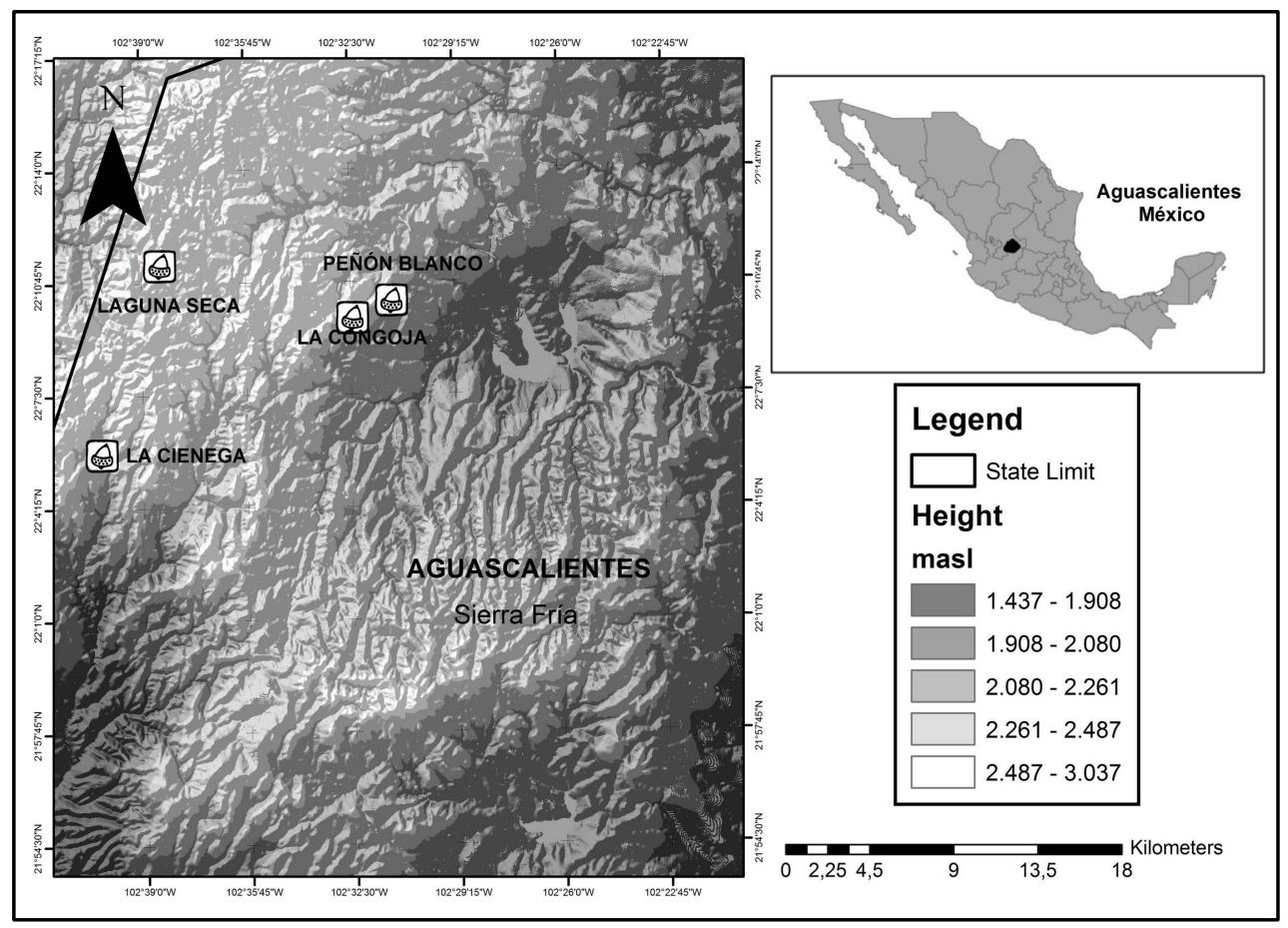

Figure 1. Collection sites of acorns in the Sierra Fría Aguascalientes, Mexico. 
Table 1. Life history and ecology characteristics of oaks from Sierra Fría, Aguascalientes, Mexico.

\begin{tabular}{|c|c|c|c|c|c|}
\hline \multirow{2}{*}{ Species } & \multicolumn{5}{|c|}{ Ecology } \\
\hline & $\begin{array}{c}\text { Type of } \\
\text { Reproduction }\end{array}$ & Fruit production & Associations & Abundance & Habitat preferences \\
\hline Q. eduardii & $\begin{array}{l}\text { Sexual/clonal } \\
\text { propagation }\end{array}$ & June-September & $\begin{array}{l}\text { Q. potosina-Q. grisea- } \\
\text { Q. sideroxylla-Q. resinosa }\end{array}$ & $\begin{array}{l}\text { The most abundant } \\
\text { together with } Q \text {. potosina }\end{array}$ & $\begin{array}{l}\text { In Mesic forest with much litter on } \\
\text { the ground and open \& close canopy }\end{array}$ \\
\hline Q. grisea & Sexual & June-September & Q. potosina-Q. eduardii & Less abundant & $\begin{array}{l}\text { In Dry/Mesic forest with little litter } \\
\text { on the ground with open canopy }\end{array}$ \\
\hline Q. potosina & $\begin{array}{l}\text { Sexual/clonal } \\
\text { propagation }\end{array}$ & June-September & $\begin{array}{l}\text { Q. eduardii-Q. grisea- } \\
\text { Q. sideroxylla }\end{array}$ & $\begin{array}{l}\text { The most abundant } \\
\text { together with } Q \text {. eduardii }\end{array}$ & $\begin{array}{l}\text { In Mesic forest with much litter on } \\
\text { the ground and open \& close canopy }\end{array}$ \\
\hline Q. resinosa & Sexual & June-September & Q. eduardii-Q. potosina & Less abundant & $\begin{array}{l}\text { In Dry forest with lower litter on the } \\
\text { ground with open canopy }\end{array}$ \\
\hline Q. sideroxyla & $\begin{array}{l}\text { Sexual/clonal } \\
\text { propagation }\end{array}$ & $\begin{array}{l}\text { September- } \\
\text { November }\end{array}$ & Q. eduardii-Q. potosina & The least abundant & $\begin{array}{l}\text { In wet forest with much litter on the } \\
\text { ground and closed canopy }\end{array}$ \\
\hline
\end{tabular}

\subsection{Acorn Viability}

The floating method is economic and was used to identify viable acorns (Gribko \& Jones, 1995). All were placed in vessels containing water and those that floated were considered dead (probably due to endosperm destruction by insects or rotting), whereas those that sank immediately were considered as viable. Usually, viable acorns are free from fungi or insects and therefore, the endosperm and embryo are ready to germinate (Hartmann \& Kester 1981); acorn infestation was also recorded.

\subsection{Acorn Size Classification}

Viable acorns of each species were weighed on an analytical scale of $0.001 \mathrm{~g}$ (VP213CN Ohaus Corporation, Pine Brook, NJ, USA) then classified according to their fresh weight in three categories (small, medium and large) (Table 2). Acorn size categories were established qualitatively to get similar sample size, for a balanced statistic design.

\subsection{Germination}

Acorns from each species and size category were completely immersed in tap water for 24 hours. When recovered from the water they were planted in closed plastic boxes containing wet agrolite. The boxes were then placed in a green house at the Autonomous University of Aguascalientes. Acorns were watered weekly and germination was registered every week during three months. An acorn was considered germinated when its radicle was $5 \mathrm{~mm}$ long. Germination percentage data were analysed with a Kruskal-Wallis test (Zar, 1984) using the JMP software (SAS Institute Inc., 2001).

\subsection{Growth and Survival}

Once the radicle was approximately $1.5 \mathrm{~cm}$ long, seedlings were placed in individual plastic bags with a mixture of $40 \%$ soil, $50 \%$ litter and $20 \%$ agrolite. Soil and litter were collected from each species collection site and acorns were sown in their corresponding mixture. Growth (shoot height) and survival were recorded weekly during ten months. One-way ANOVA for each species was used to evaluate growth and survival of seedlings from three acorn size classes, using the JMP software (SAS Institute Inc., 2001). Survival data were arcsentransformed to stabilize the variance.

\section{Results}

Acorn viability varied among species (Figure 2) with Q. sideroxyla showing the lowest viability (25\%), and $Q$. grisea the highest (85\%). In the other hand, the lowest infestation by species of the Curculionidae family was 
Table 2. Category sizes of acorns according to their weight (small, medium and large) of five species of oaks from Sierra Fría, Aguascalientes, Mexico. Last column shows the average weight ( $\pm 1 \mathrm{SD}$ ) of acorns of each species.

\begin{tabular}{ccccc}
\hline Species & Small & Medium & Large & Mean \pm 1 SD \\
\hline Q. sideroxyla & $<0.50$ & $0.51-0.70$ & $>0.71$ & $0.63 \pm 0.22^{\mathrm{ab}}$ \\
Q. eduardii & $<0.60$ & $0.61-0.70$ & $>0.71$ & $0.54 \pm 0.08^{\mathrm{a}}$ \\
Q. resinosa & $<1.60$ & $1.61-2.50$ & $>2.51$ & $2.55 \pm 1.35^{\mathrm{c}}$ \\
Q. potosina & $<1.07$ & $1.08-1.51$ & $>1.51$ & $1.58 \pm 0.72^{\mathrm{bc}}$ \\
Q. grisea & $<0.60$ & $0.61-0.85$ & $>0.86$ & $0.60 \pm 0.38^{\mathrm{ab}}$ \\
\hline
\end{tabular}

Different lower-case letters indicate significant differences among acorn sizes for each species $(P<0.05)$.

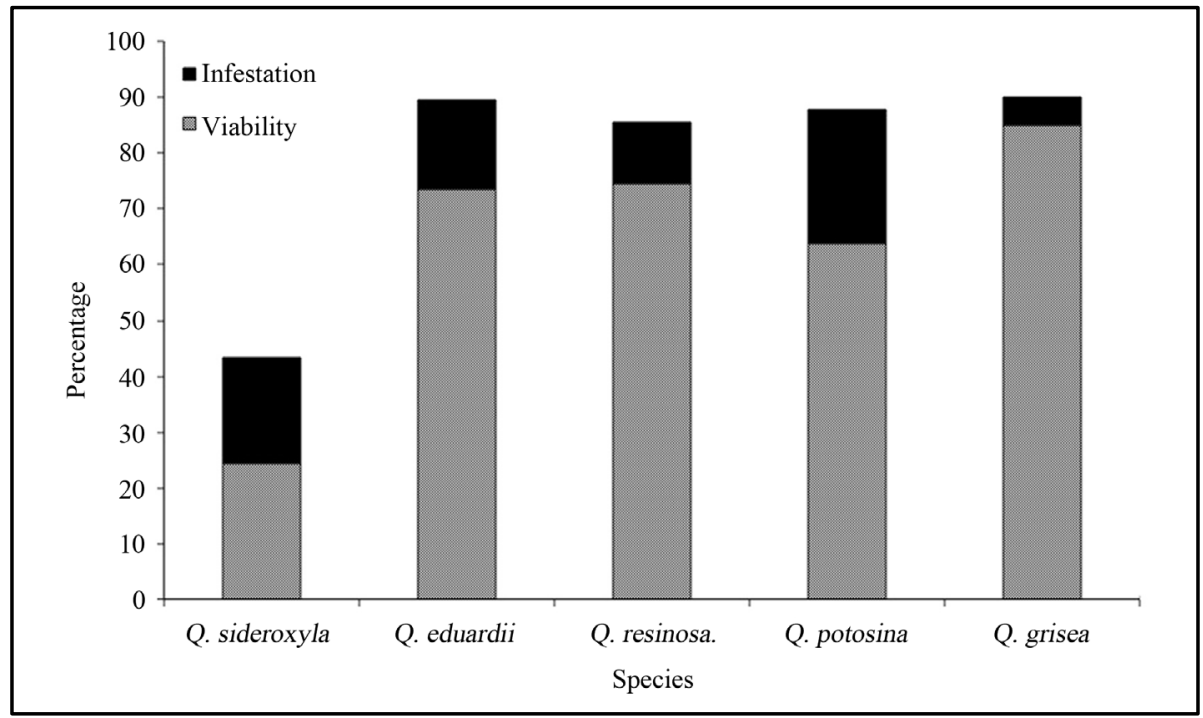

Figure 2. Acorn viability (\%) and infestation by curculionids (\%) of five species of Quercus in Sierra Fría, Aguascalientes, Mexico.

found in Q. grisea (15\%), whereas the highest was found in Q. potosina (24\%) and Q. sideroxyla (19\%) (Figure 2). Additionally, acorn weight also varied among Quercus species (Table 2). Acorn size range varied for each species. Mean acorn size category were different among species according to a one-way ANOVA (Table 2). Mean acorn weight of $Q$. resinosa was significantly higher $(P<0.05)$ than $Q$. eduardii.

Germination percentages for acorns of different category sizes in the five species of Quercus are shown in Figure 3. Germination was significantly higher in medium size acorns of Q. sideroxyla, Q. eduardii and $Q$. potosina $\left(\mathrm{X}^{2}=15.5 ; P<0.05\right)$, whereas in $Q$. resinosa and $Q$. grisea germination was significantly higher in the largest size class $\left(X^{2}=24.95 ; P<0.05\right)$. However, at species level, $Q$. grisea showed a significantly higher acorn germination percentage than $Q$. resinosa $\left(X^{2}=4.057 ; P<0.05\right)$. The other three species showed intermediate germination percentages that also differ from $Q$. sideroxyla $\left(\mathrm{X}^{2}=3.47 ; P<0.05\right)$.

Seedlings of Q. eduardii, Q. potosina and Q. sideroxyla, showed no significant differences in shoot height among small, medium and large acorn category sizes (Figure 4). However, seedlings from the largest acorn sizes of $Q$. grisea and $Q$. resinosa were significantly taller than seedlings from medium and small acorn size ( $\mathrm{F}=49.02 ; P=0.002)$. At species level, seedlings shoot height did not differ among the types.

Finally, our results showed that survival percentage was significantly higher in medium size acorns of $Q$. sideroxyla, $Q$. eduardii and $Q$. potosina $(\mathrm{F}=23.45 ; P=0.01)$, whereas in $Q$. resinosa $(\mathrm{F}=25.01 ; P=0.001)$ survival was significantly higher in the largest size class and $Q$. grisea $(\mathrm{F}=24.95 ; P=0.001)$ were significantly higher in the medium and largest size class. However, at species level, Q. resinosa showed a significantly lower survival percentage than the other species, with the exception of $Q$. eduardii $(F=4.057 ; P=0.05)($ Figure 5). 


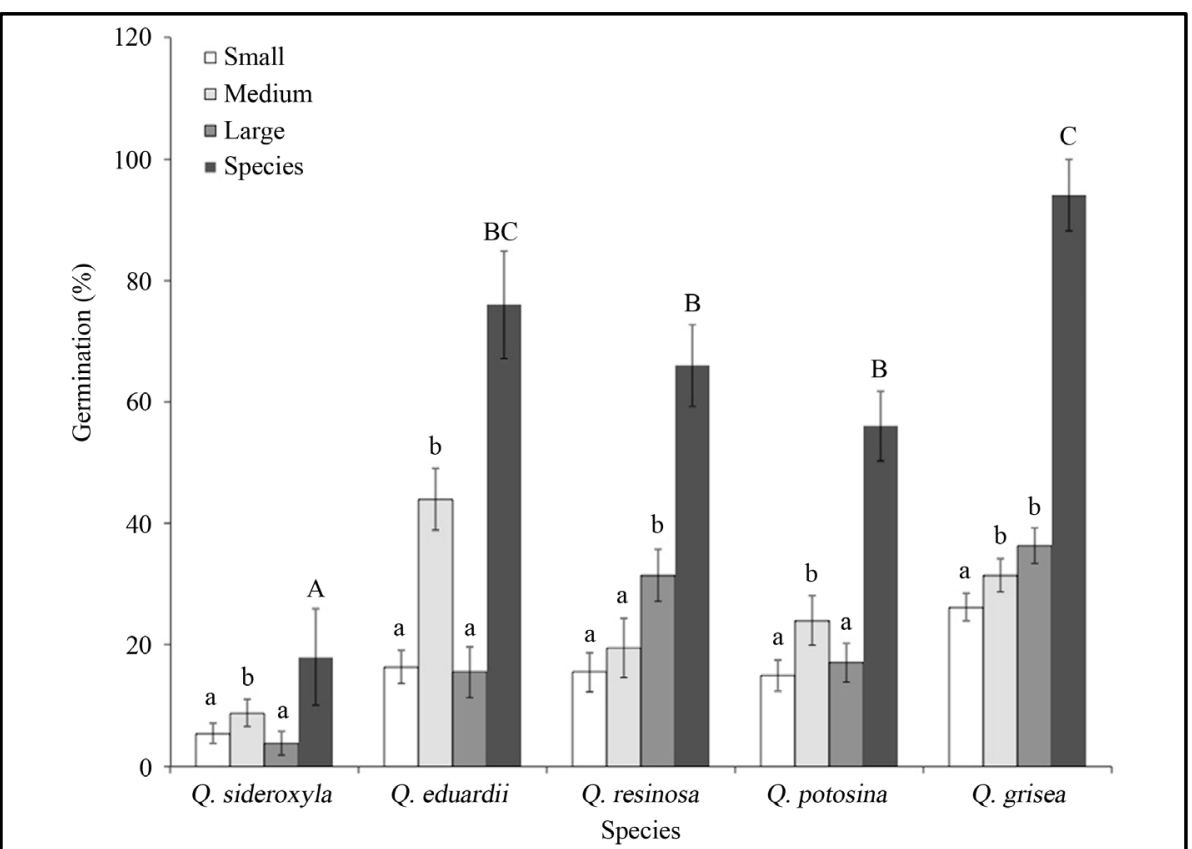

Figure 3. Germination (\%) in acorn size classes of five species of Quercus in Sierra Fría, Aguascalientes, Mexico, and mean germination (\%) of each species. Different lower-case letters indicate significant differences among acorn sizes for each species $(P<0.05)$. Different capital letters indicate significant differences among species $(P<0.05)$.

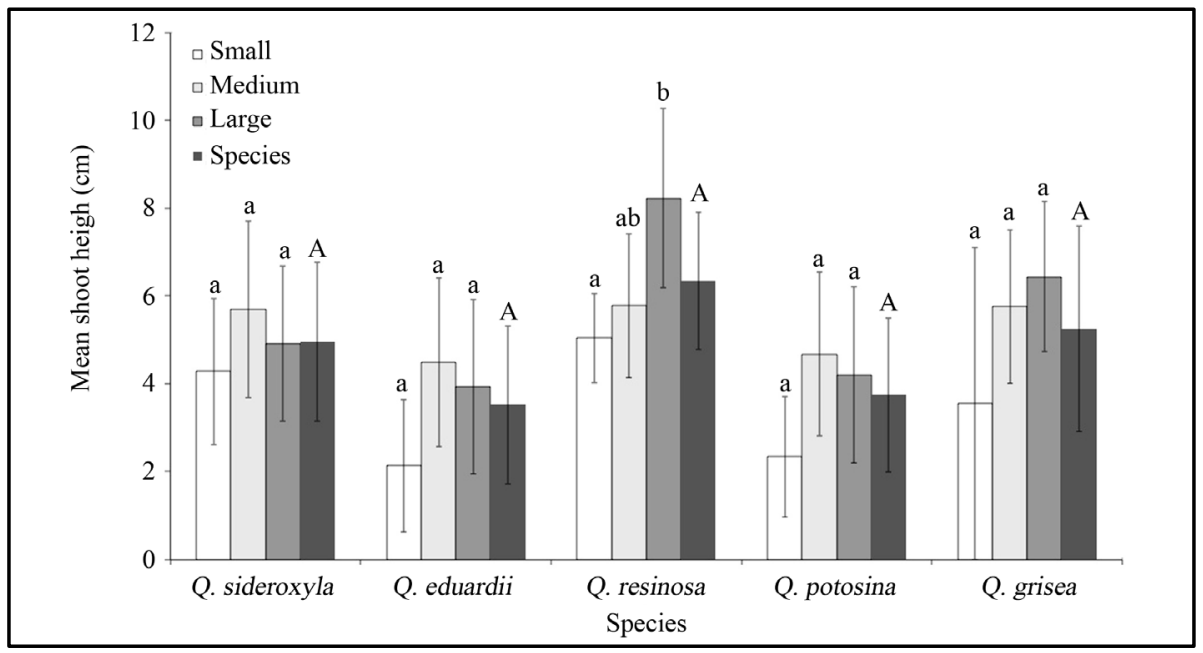

Figure 4. Mean shoot height $(\mathrm{x} \pm 1 \mathrm{SD})$ of seedling from small, medium and large acorn sizes of five species of Quercus in Sierra Fría, Aguascalientes, Mexico, and mean shoot height for each species. Different lower-case letters indicate significant differences in shoot height among acorn size classes for each species $(P<0.05)$. Same capital letters indicate no significant differences in shoot height among species $(P<0.05)$.

\section{Discussion}

The number and size of seeds produced in the genus Quercus species are important in population level adaptation, since it ensures the establishment and growth of seedlings (Quero et al., 2007; Yi \& Yang, 2010). According to Branco et al. (2002), the process of establishing a new seedling must start by evaluating the viability and seed infestation. This is crucial because viable seed selection is fundamental to guarantee the success of conservation programs and the restoration of species with regeneration problems (Martinez et al., 2006). 


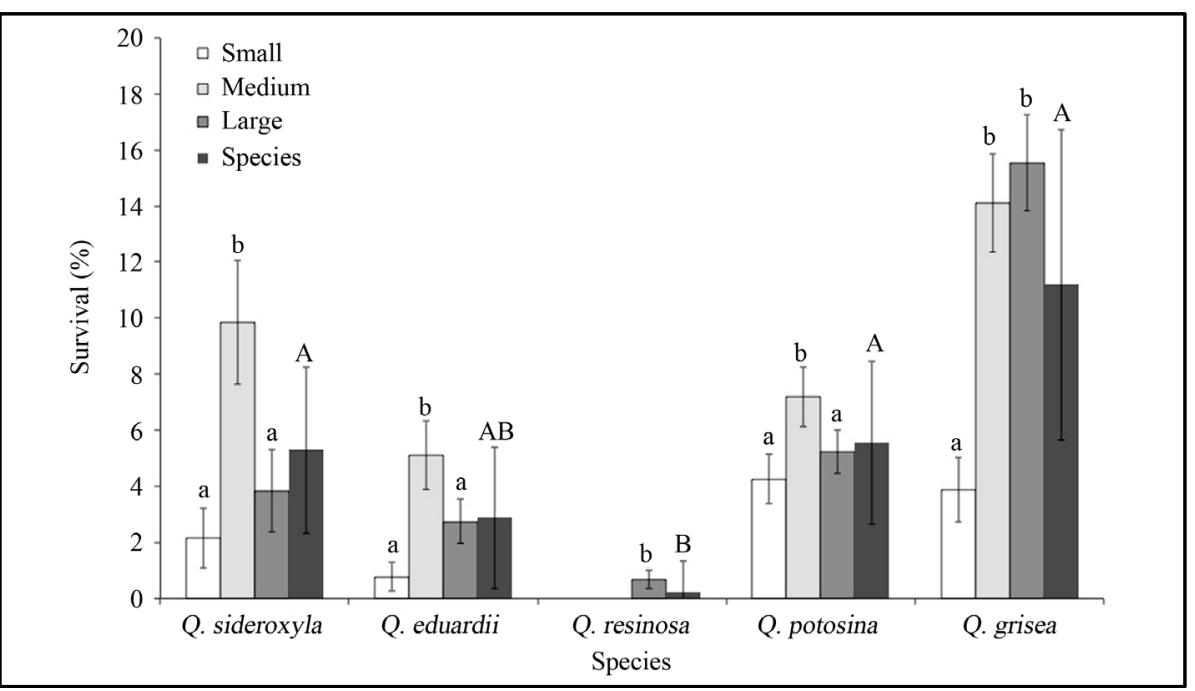

Figure 5. Survival (\%) of seedlings from different acorn sizes of five species of Quercus in Sierra Fría, Aguascalientes, Mexico, and mean survival (\%) of each species. Different lower-case letters indicate significant differences in survival among acorn size classes for each species $(P<0.05)$. Same capital letters indicate no significant differences in survival among species $(P<0.05)$.

Oak species suffer high insect infestation that reduces viability and germination of acorns (Gomez et al., 2003). In our study, the percentages of infestation by beetle larvae (Coleoptera: Curculionoidea) are low $(<25 \%)$ compared to the averages of over $40 \%$ reported in other oak species from America (Thadani \& Ashton, 1995; Gomez et al., 2003), Asia (Hou et al., 2010; Yi \& Yang, 2010) and Europe (Csóka \& Hirka, 2006). There are also different methods for collecting seeds, which can influence the viability of the acorn (Bonner, 2003). In this study the seeds were collected directly from the tree according to Zavala-Chávez (2004), and according to our results this method could be recommend to be employed in subsequent regional studies.

It has been documented that infested seeds with little endosperm damage may germinate in the same way as undamaged acorns and generate healthy seedlings (Gribko et al., 2002; Xiao et al., 2007). It was found that 20 to 30 percent of infested seeds germinated in the five species. However, none of the seedlings survived for more than three months. In this study, we do not recommend the use of infested seeds (those with evidence of small holes or that float in water) in reforestation or restoration. Significant damage to the endosperm and embryo can occur in the infested seed (Fukumoto \& Kajimura, 2000; Hou et al., 2010), resulting in vain work efforts and economic resource investment, as well as to obtain negative results when establishing plants.

Seed size is an important feature that influences plant fitness (Harper, 1977; Dalling \& Hubbell, 2002), but it may be influenced by the environment (Willan, 1985; Takahashi et al., 2011). We found different evolutionary strategies present in the sexual regeneration of species. Two oak species have sexual reproduction only, Quercus grisea and Q. resinosa, where the large seed size has the highest percentage of germination, survived and grew. Large seeds confer evolutionary advantages by allowing larger cotyledons and rapid movement of its reserves (Branco et al., 2002), increased drought resistance (Takahashi et al., 2011) and increased germination and seedling development (Navarro et al., 2006; Quero et al., 2007). These two species inhabit dry, open forests with little mulch on the ground; hence their seeds are exposed to rapid drying. In semi-xeric forests like Aguascalientes, recalcitrant seed death is usually rapid (Zavala-Chavez, 2004), so the recruitment of large seeds is crucial to successful establishment (Eriksson \& Jakobsson 1998; Dalling \& Hubbell, 2002).

However, the medium size category with the highest germination, seedling survival and growth were present in $Q$. eduardii, Q. potosina and Q. sideroxyla. These three species exist in a less arid habitat and have clonal propagation and mast-seeding years (Alfonso-Corrado et al., 2007) unlike Q. grisea and Q. potosina. In oak species that have mast seeding, predators have been shown to preferred large seed (Pons \& Breaks, 2007). This finding appears to represent an evolutionary disadvantage for the species, but we have observed that 
smaller seed size improves resistance to depredation, thus ensuring the successful establishment of seedlings (Gomez, 2004; Yi \& Yang, 2010).

A heuristic model developed by Ericksson \& Jakobsson (1998) suggests that a medium seed size allows for greater distribution and regional abundance of the species. Q. eduardii and Q. potosina combine vegetative propagation with sexual reproduction and, due to these being the most abundant species in the Sierra Fria (Alfonso-Corrado et al., 2004; Alfonso-Corrado et al., 2007), the higher fitness of their medium-size acorns seem to function efficiently. Additionally, $Q$. sideroxyla is a species that has specific environmental requirements and a very small niche (Alfonso-Corrado et al., unpublished dates), so it is likely that these same strategies have allowed it to survive. However, future studies are needed to validate this theory.

An understanding of basic biological regeneration at a local scale of five oak species is important because these species present genetic adaptation and local ecology (Alfonso-Corrado et al., 2004, 2007; Rosas-Osorio et al., 2010; Gorgonio-Ramírez, 2012). Choosing the right seed size for reforestation or restoration in disturbed areas of Sierra Fría not only involves the mass production of plants, but also an understanding of their reproductive strategies and the environmental requirements of the species as suggests Vieira \& Scariot (2006). Likewise, restoration programs should understand that the fruit size is not a good attribute for comparisons among species because acorn size does not uniformly influence germination percentage, growth or survival among species.

In this work, recommendations for reforestation or restoration programs in the Sierra Fría advocates the collection of large seeds only in Quercusgrisea and Q. resinosa, and large and medium size seeds in $Q$. eduardii, Q. potosina and Q. sideroxyla. After collection, viable seeds must be selected, germinate them in a greenhouse for six months allowing an adequate growth, then planting a mix of native oak species in the early rainy season facilitates the development of seedlings and may be sufficient for restoration of the degraded forest. This strategy could be appropriate for severely disturbed forests where there usually are altered abiotic parameters, and on which more than $70 \%$ of the survival of regenerated plants depend (Clark-Tapia et al., unpublished dates) and ensures the recovery of the Sierra Fria, an area that has been historically subjected to livestock management.

\section{Acknowledgements}

We thank to Sierra Fría people and José Medina Flores from Instituto de MedioAmbiente del Estado de Aguascalientes for their logistic support of our fieldwork. Margarita de la Cerda to identify these species. We are also grateful to Tania Sánchez and Francisco Naranjo. Financial support was provided by CONAFORCONACYT (14074).

\section{References}

Alfonso-Corrado, C., Esteban-Jiménez, R., Clark-Tapia, R., Piñero, D., Campos, J. E., \& Mendoza, A. (2004). Clonal and Genetic Structure of Two Mexican Oaks: Quercuseduardii and Q. potosina (Fagaceae). Evolutionary Ecology, 18, 585-599. http://dx.doi.org/10.1007/s10682-004-5145-5

Alfonso-Corrado, C., Clark-Tapia, R., \& Mendoza, A. (2007). Demography and Management of Two Clonal Oaks: Quercuseduardii and Q. potosina (Fagaceae) in Central Mexico. Forest Ecology and Management, 251, 129-141. http://dx.doi.org/10.1016/j.foreco.2006.11.004

Bonner, F. T. (2003). Collection and Care of Acorns: A Practical Guide for Seed Collectors and Nursery Managers. http://www.nsl.fs.fed.us/COLLECTION\%20AND\%20CARE\%200F\%20ACORNS.pdf

Branco, M., Branco, C., Merouami, H., \& Almeida, M. H. (2002). Germination Success, Survival and Seedling Vigor of Quercussuber Acorns in Relation to Insect Damage. Forest Ecology and Management, 166, 159-164. http://dx.doi.org/10.1016/S0378-1127(01)00669-7

Brown, S., \& Lugo, A. E. (1994). Rehabilitation of Tropical Lands: A Key to Sustaining Development. Restoration Ecology, 2, 97-111. http://dx.doi.org/10.1111/j.1526-100X.1994.tb00047.x

Cervantes, V., Carabias, J., \& Arriaga, V. (2008). Evolución de las políticas públicas de restauración ambiental. In Conabio (Ed.), Capital Natural de México, Políticas Públicas y Perspectivas de Sustentabilidad (Vol. III, pp. 155-226). México, D.F.: Comisión Nacional para el Conocimiento y Uso de la Biodiversidad.

Challenger, A. (1998). Utilización y conservación de los ecosistemas terrestres de México. Pasado, presente y futuro. México, D.F.: CONABIO-UNAM-SIERRA MADR.

Chapa-Bezanilla, D., Sosa-Ramírez, J., \& de Alba-Ávila, A. (2008). Estudio Multitemporal de los Bosques de Sierra Fría, 
Aguascalientes, México. Maderas y Bosques, 14, 37-51.

Chazdon, R. L. (2008). Beyond Deforestation: Restoring Forests and Ecosystem Services on Degraded Lands. Science, 320, 1458-1460. http://dx.doi.org/10.1126/science.1155365

Chazdon, R., Harvey, C. A., Komar, O., Griffith, D. M., Ferguson, B. G., Martinez-Ramos, M., et al. (2009). Beyond Reserves: A Research Agenda for Conserving Biodiversity in Human-modified Tropical Landscapes. Biotropica, 41, 141153. http://dx.doi.org/10.1111/j.1744-7429.2008.00471.x

Csóka, G, \& Hirka, A. (2006). Acorn Infections in Hungary: Direct and Indirect Effects on Oaks’ Fecundity. Gmundsen, Austria: IUFRO Proceedings of the Workshop, 109-120.

Dalling, J. W., \& Hubbell, S. P. (2002). Seed Size, Growth Rate and Gap Microsite Conditions as Determinants of Recruitment Success for Pioneer Species. Journal of Ecology, 90, 557-568. http://dx.doi.org/10.1046/j.1365-2745.2002.00695.x

Daws, M., Garwood, N., \& Pritchard, H. (2005).Traits of Recalcitrant Seeds in a Semi-Deciduous Tropical Forest in Panamá. Functional Ecology, 19, 874-885. http://dx.doi.org/10.1111/j.1365-2435.2005.01034.x

del Moral, R., Walker, L. R., \& Bakker, J. P. (2007). Insights Gained from Succession for the Restoration of Landscape Structure and Function. In L. R. Walker, J. Walker, \& R. J. Hobbs (Eds.), Linking Restoration and Ecological Succession, (pp. 19-44). New York, NY: Springer Science+Business Media, LLC.

Eriksson, O., \& Jakobsson, A. (1998). Recruitment Trade-Offs and the Evolution of Dispersal Mechanisms in Plants. Evolutionary Ecology, 13, 411-423. http://dx.doi.org/10.1023/A:1006729311664

Esquivel, J. M., Harvey, C. A., Finegan, B., Casanoves, F., \& Skarpe, C. (2008). Effects of Pasture Management on the Natural Regeneration of Neotropical Trees. Journal of Applied Ecology, 45, 371-380.

http://dx.doi.org/10.1111/j.1365-2664.2007.01411.x

Fukumoto, H., \& Kajimura, H. (2000). Effects of Insects Predation on Hypocotyl Survival and Germination Success of Mature Quercusvariabilis Acorns. Journal of Forest Research, 5, 31-34. http://dx.doi.org/10.1007/BF02762760

Gomez, J. M., García, D., \& Zamora, R. (2003). Impact of Vertebrate Acorn and Seedling-Predators on a Mediterranean Quercuspyrenaica Forest. Forest Ecology and Management, 180, 125-134. http://dx.doi.org/10.1016/S0378-1127(02)00608-4

Gomez, J. M. (2004). Bigger is not Always Better: Conflicting Selective Pressures on Seed Size in Quercus ilex. Evolution, 58, 71-80.

Gorgonio-Ramírez, M. (2012). Variabilidad y estructura genética de Quercus eduardii (Fagaceae) en Sierra Fría, Aguacalientes. Unpublished BSc Thesis, Oaxaca, México: Universidad de la Sierra Juárez, Ixtlán de Juárez.

Greipsson, S. (2011). Restoration Ecology. Sudbury, MA: Jones \& Bartlett Learning, LLC.

Gribko, L. S., \& Jones, W. E. (1995). Test of the Float Method of Assessing Northern Red Oak Acorn Viability. Tree Planter's Notes, 46, 143-147.

Gribko, L. S., Schuler, T. M., \& Ford, W. M. (2002). Biotic and Abiotic Mechanisms in the Establishment of Northern Red Oak Seedlings: A Review. US Department of Agriculture, Forest Service, Northeastern Research Station.

Harper, J. L. (1977). Population Biology of Plants. New York, NY: Academic Press, 892 p.

Hartmann, H. T., \& Kester, D. E. (1981). Propagación de Plantas. México, D.F.: CECSA, 814 p.

Hou, X., Yi, X., Yang, Y., \& Liu, W. (2010). Acorn Germination and Seedling Survival of Q. variabilis: Effects of Cotyledon Excision. Annals of Forest Science, 67, 711. http://dx.doi.org/10.1051/forest/2010036

Kajimura, H., \& Fukomoto, H. (2005). Cumulative Effects of Mortality on Reproductive Output in Two Co-Occurring Quercus Species: Which Mortality Factors Most Strongly Reduce Reproductive Potential? Canadian Journal of Botany, 83, 1151-1158. http://dx.doi.org/10.1139/b05-090

Kermode, A. R., \& Finch-Savage, W. E. (2002). Desiccation Sensitivity in Orthodox and Recalcitrant Seeds in Relation to Development. In M. Black, \& H. W. Pritchard (Eds.), Desiccation and Survival in Plants. Drying without Dying (pp. 149-184). Wallingford: CABI Publishing. http://dx.doi.org/10.1079/9780851995342.0149

Kelly, D., \& Sork, V. L. (2002). Mast Seeding in Perennial Plants: Why, How, Where? Annual Review of Ecology and Systematics, 33, 427-447. http://dx.doi.org/10.1146/annurev.ecolsys.33.020602.095433

Lamb, D., \& Gilmour, D. (2003). Rehabilitation and Restoration of Degraded Forests. Gland, Switzerland: IUCN, Gland, Switzerland and Cambridge, UK and WWF, $110 \mathrm{p}$.

Lamb, D., Erskine, P. D., \& Parrotta, J. A. (2005). Restoration of Degraded Tropical Forest Landscapes. Science, 310, 16281632. http://dx.doi.org/10.1126/science.1111773

Martinez, P. G., Orozco, S. A., \& Martorell, C. (2006). Efectividad de Algunos Tratamientos Pre-Germinativos para Ocho Especies Leñosas de la Mixteca Alta Oaxaqueña con Características Relevantes para la Restauración. Boletín de la 
Sociedad Botánica de México, 79, 9-20.

Masera, O., Astier, M., \& López-Ridaura, S. (1999). Sustentabilidad y manejo de recursos naturales, el marco de evaluación MESMIS. México, D.F.: Multiprensa/GIRA/Instituto de Ecología, UNAM, 109 p.

Minnich, R., Sosa-Ramírez, J., Franco-Vizcaíno, E., Barry, W. J., \& Siqueiros, M. (1994). Reconocimiento Preliminar de la Vegetación y de los Impactos de las Actividades Humanas en la Sierra Fría, Aguascalientes. Revista Investigación y Ciencia, 4, 23-29.

Navarro, F. B., Jiménez, M. N., Ripoll, M. Á., Fernández-Ondoño, E., Gallego, E., \& De Simón, E. (2006). Direct Sowing of Holm Oak Acorns: Effects of Acorn Size and Soil Treatment. Annals of Forest Science, 63, 961-967. http://dx.doi.org/10.1051/forest:2006079

Pons, J., \& Pausas, J. G. (2007). Not Only Size Matters: Acorn Selection by the European Jay (Garrulus glandarius). Acta Oecologica, 31, 353-360. http://dx.doi.org/10.1016/j.actao.2007.01.004

Quero, J. L., Villar, R., Marañón, T., Zamora, R., \& Poorter, L. (2007). Seed-Mass Effects in Four Mediterranean Quercus Species (Fagaceae) Growing in Contrasting Light Environments. American Journal of Botany, 94, 1795-1803. http://dx.doi.org/10.3732/ajb.94.11.1795

Rosas-Osorio, J. C., Alfonso-Corrado, C., Monsalvo-Reyes, A., Clark-Tapia, R., Lira-Saade, R., \& Campos-Contreras, J. (2010). The Genetic Variability of Quercus grisea Liebm. in the Sierra Fría of Aguascalientes, México. International Oak Journal, 21, 64-72.

SAS, Institute Inc. (2001). SAS® Version 8.1 [Computer Program]. Cary, N.C.: SAS Institute Inc.

Secretaria de Desarrollo Social (SEDESO) (1993). Estudio para la declaratoria de la Sierra Fría como Área Natural Protegida. Aguascalientes, México.

Segura-Burciaga, S. G. (2005). Las especies introducidas: ¿benéficas o dañinas?. In Ó. Sánchez, E. Peters, R. MárquezHuitzil, E. Vega, G. Portales, M. Valdez, \& D. Azuara (Eds.), Temas sobre restauración ecológica (pp. 127-134). México, D.F.: Secretaría de Medio Ambiente y Recursos Naturales Instituto Nacional de Ecología U.S. Fish \& Wildlife Service Unidos para la Conservación, A.C.

Shono, K., Cadaweng, E. A., \& Durst, P. B. (2007). Application of Assisted Natural Regeneration to Restore Degraded Tropical Forest Lands. Restoration Ecology, 15, 620-626. http://dx.doi.org/10.1111/j.1526-100X.2007.00274.X

Takahashi, A., Shibata, M., \& Shimada, T. (2011). Variation in Seed Production Schedule Among Individual Trees of a Deciduous Oak Species Quercus serrata: Its Relation to Seed Characteristics. Plant Ecology, 212, 1527-1535. http://dx.doi.org/10.1007/s11258-011-9928-9

Thadani, R., \& Ashton, P. M. S. (1995). Regeneration of Bank Oak (Quercus leucotrichophora A. Camus) in the Central Himalaya. Forest Ecology and Management, 78, 217-224. http://dx.doi.org/10.1016/0378-1127(95)03561-4

Valencia-Avalos, S. (2004). Diversidad del Género Quercus (Fagaceae) en México. Revista de la Sociedad Botánica de México, 75, 33-53.

Vázquez-Yanez, C., Batis Muñoz, A. I., Alcocer Silva, M. I., Gual-Díaz, M., \& Sánchez-Dirzo, C. (1999). Árboles y arbustos potencialmente valiosos para la restauración ecológica y la reforestación. México, D.F.: Reporte técnico del proyecto J084. Comisión Nacional para el Conocimiento y Uso de la Biodiversidad e Instituto de Ecología, UNAM.

Vieira, D. L. M., \& Scariot, A. (2006). Principles of Natural Regeneration of Tropical Dry Forests for Restoration. Restoration Ecology, 14, 11-20. http://dx.doi.org/10.1111/j.1526-100X.2006.00100.X

Willan, R. L. (1985). A Guide to Forest Feed Handling. FAO Forestry Paper. FAO, Rome, 20/2.

Xiao, Z., Harris, M. K., \& Zhang, Z. (2007). Acorn Defenses to Herbivory from Insects: Implications for the Joint Evolution of Resistance, Tolerance and Escape. Forest Ecology and Management, 238, 302-308. http://dx.doi.org/10.1016/j.foreco.2006.10.024

Yi, X. F., \& Yang, Y. Q. (2010). Large Acorns Benefit Seedling Recruitment by Satiating Weevil Larvae in Quercus aliena. Plant Ecology, 209, 291-300. http://dx.doi.org/10.1007/s11258-010-9730-0

Zavala-Chávez, F. (2004). Desecación de Bellotas y su Relación con la Viabilidad en Nueve Especies de Encinos Mexicanos. Ciencia Ergo Sum, 11, 177-185

Zavala-Chávez, F., \& García-Moya, E. (1997). Plántulas y Rebrotes en la Regeneración de Encinos en la Sierra de Pachuca, Hidalgo. Agrociencia, 31, 323-329. 